\title{
THE CLINICAL USE OF PITUITARY GONADOTROPHINS IN WOMEN
}

\author{
C. A. GEMZELL, P. ROOS AND F. E. LOEFFLER* \\ Department of Obstetrics and Gynaecology, Akademiska Sjukhuset, \\ University of Uppsala, and Institute of Biochemistry, \\ University of Uppsala
}

\section{INTRODUCTION}

On 22nd January 1926, in lectures to the 'Gesellschaft für Geburtshilfe und Gynäkologie zu Berlin', Zondek (1926) and Aschheim (1926) first made public the results of experiments on the intact immature mouse which demonstrated that the anterior pituitary contained substances which could stimulate the ovaries. They called the anterior pituitary 'Motor der Sexualfunktion'. As with many of the most brilliant advances in medicine, their findings were confirmed by simultaneous but independent experiments on intact animals and hypophysectomized rats by Smith (1926) and Smith \& Engle (1927) at Stanford University, California. Zondek and Aschheim ultimately suggested that there were two gonadotrophic substances in the anterior pituitary, one responsible for follicular development and the other for corpus luteum formation after follicular rupture. They called them 'Hypophysenvorderlappenhormon A, (HVH-A) and 'HVH-B'.

These concepts are very similar to present-day teaching about the mechanisms involved in ovulation. It is now confirmed that there are two separate gonadotrophic substances: follicle-stimulating hormone (FSH) and luteinizing hormone (LH) also known as interstitial cell stimulating hormone (ICSH). At the onset of a menstrual cycle, under the influence of FSH from the anterior pituitary a number of follicles begin to develop and secrete oestrogen which causes endometrial proliferation. All but one of the follicles, for reasons unknown, become atretic. At about mid-cycle, under the added influence of a surge of $\mathrm{LH}$, the favoured FSH-primed follicle ruptures with discharge of an ovum. The ruptured follicle is then transformed into a corpus luteum in which progesterone and small amounts of oestrogen are formed. The progesterone leads to secretory changes in the endometrium. In gynaecological practice human gonadotrophins are almost exclusively used for attempts to induce ovulation by imitating the sequential release of FSH and $\mathrm{LH}$ from the anterior pituitary. In women there is no evidence for the dependence of the corpus luteum on a third hormone, prolactin or luteotrophic hormone (LTH), as is the case with experimental animals.

\footnotetext{
* Population Council Fellow, 1965-66. Senior Registrar in Obstetrics and Gynaecology, The London Hospital, London, E.1, and the North-East Metropolitan Regional Hospital Board.
} 
The anterior pituitary is itself under hypothalamic control and this is mediated by the various 'releasing factors' and the portal-hypophysial circulation. The hypothalamus can be influenced by impulses from higher centres. Its activity can also be modified by the ovarian sex steroids, themselves the result of gonadotrophic activity. An ovarian-pituitary 'feed-back' mechanism therefore exists which forms the basis of cyclical pituitary-ovarian function, ovulation and menstruation. A detailed consideration of these topics, while relevant, is beyond the scope of this article.

It is proposed to limit this account to a brief review of gonadotrophin preparations which have been used clinically and then to concentrate on those extracts made from human sources, particularly the hypophysis. In doing so it is a great privilege to join in a tribute to Bernhard Zondek who was instrumental in setting off the chain reaction which has led to our current knowledge and problems in the field of human gonadotrophins.

\section{GONADOTROPHIN PREPARATIONS IN GLINICAL USE}

\section{FOLLICLE STIMULATING SUBSTANCES}

\section{Animal origin}

Pregnant mare's serum (PMs), bovine, ovine and porcine pituitaries constitute the main sources of extracts containing follicle-stimulating activity. These substances, alone or in combination with human chorionic gonadotrophin (HCG) have received extensive clinical trial. The fact that Muller (1962) was able to collect thirty-nine reported cases of 'hyperstimulation syndrome' between 1942 and 1961 certainly indicates that this form of therapy was not without effect on human ovaries. In terms of induced ovulation, however, the results obtained showed a lack of consistency (see Kotz \& Herrmann, 1961) and treatment with animal hormones has now been largely abandoned.

There are many possible explanations for these early failures. Rigid criteria were not always used in the selection of cases. There was a lack of adequate controls. No uniformity in dosages or methods of administration existed. But probably most important of all were interference from antibodies to FSH from animal sources (see Ostergaard, 1964) and problems of species specificity. Not until these obstacles were removed was the way clear for encouraging and reproducing results with induced ovulation.

\section{Human origin}

In 1958 an FSH extract obtained from human pituitaries was tested on seven patients (Gemzell, Diczfalusy \& Tillinger, 1958). There was little doubt about its ability to stimulate the development of Graafian follicles and, with HCG treatment, to lead to ovulation and corpus luteum formation. Since then these effects have been repeatedly confirmed (Apostolakis, Bettendorf \& Voigt, 1962; Bettendorf, 1962, 1963, 1964; Bettendorf \& Breckwoldt, 1964, 1965; Buxton, 1961; Buxton \& Herrmann, 1960, 1961; Buxton, Kase \& Van Orden, 1963; Crooke, 1964; Crooke, Butt, Palmer, Morris, Edwards \& Anson, 1963a; Crooke, Butt, Palmer, Morris, Edwards, Taylor \& Short, 1963b; Crooke, Butt, Carrington, Morris, Palmer \& Edwards, 1964a; Crooke, Butt, Palmer, Bertrand, Carrington, Edwards \& Anson, 1964b; Crooke, Butt, Palmer, Morris 
\& Morgan, 1964c; Diczfalusy, Johannison, Tillinger \& Bettendorf, 1964; Gemzell, 1961, 1962a, b, 1963a, b, c, 1964, 1965a, b; Gemzell, Diczfalusy \& Tillinger, 1960; Gemzell \& Roos, 1966a, b; Grant, Meares, Ferguson \& Wallace, 1964; Rosemberg, Coleman, Gibree \& MacGillivray, 1962).

It is of interest to note that Zondek, as early as July 1925, had performed an experiment demonstrating the gonadotrophic hormone content of the anterior pituitary. The gland was obtained post-mortem from a case of pulmonary embolism after myomectomy. By implanting it into three immature mice weighing 8 to $10 \mathrm{~g}$ precocious ovarian and genital tract development was induced in all test animals (Zondek, 1931).

Fluhman (1929) and Zondek (1930) separately described a gonadotrophic substance in the blood and urine of menopausal women which caused follicular development in experimental animals. Not until 1960 did Lunenfeld, Menzi \& Volet (1960) report that gonadotrophins extracted from human post-menopausal urine could stimulate human ovaries. Numerous subsequent publications have supported this observation and have shown that human menopausal gonadotrophin (HMG) and HGG can induce ovulation (Borth, Lunenfeld \& Menzi 1961a; Crooke et al., 1963a, 1964b; Diczfalusy et al., 1964; Lunenfeld, 1963, 1965; Lunenfeld, Rabau, Rumney, Winkelsberg, 1961 ; Lunenfeld, Sulimovici \& Rabau, 1962; Palmer \& Dorangeon, 1962; Pasetto \& Montanino, 1964a, b; Rosemberg, Coleman, Demany \& Celso-Ramon, 1963; Rosemberg, Maher, Stern \& Demany, 1964; Staemmler, 1961; Vande Wiele \& Turksoy, 1965). The preparation in common use today is 'Pergonal' (Instituto Farmacologico Serono, Rome) and the method of its extraction has been evolved by Donini and collaborators (Donini, Puzzuoli \& Montezemolo, 1964).

\section{LUTEINIZING SUBSTANCE-HCG}

Aschheim \& Zondek (1927) reported the presence of gonadotrophic substance in the urine of pregnant women. They thought they could isolate two hormones, the one inducing follicular development and the other luteinization. They called their preparations Prolans A and B and gave the anterior pituitary as their probable site of origin. It is now known that there is only one detectable and extractable gonadotrophin, $\mathrm{HCG}$, in the urine of pregnant women, that it stems from the placental trophoblastic cells and that it is incapable of stimulating follicular growth but can cause rupture and luteinization of a mature follicle.

These facts and the ease of its extraction from human sources explain why HCG has survived through the years to emerge as the luteinizing substance in commonest use. Preparations of $\mathrm{LH}$ have, to date, only received a limited clinical trial. On physiological grounds, and by analogy with FSH, it will be desirable to test LH on patients when it is available in sufficient quantity. It is possible that it may ultimately replace HCG as the luteinizing substance of choice in controlled ovulation.

\section{HUMAN PITUITARY GONADOTROPHINS-DIFFICULTIES, DOUBTS AND CERTAINTIES}

The follicle stimulating human pituitary extracts which have been used 
clinically are variously known as human pituitary follicle stimulating hormone (HPFSH), human pituitary gonadotrophin (HPG) and human hypophysial gonadotrophin (HHG). To date, the use of these substances and HMG has very properly been confined to centres where full endocrine laboratory facilities exist and where supervision by people experienced in endocrinology, gynaecology and obstetrics is feasible. The only clear-cut indication for gonadotrophin treatment is infertility due to ovarian failure that is secondary to pituitary deficiency.

\section{TABLE 1}

MEASURING THE POTENCY OF AN FSH PREPARATION BEFORE GLINICAL USE

\begin{tabular}{|c|c|c|c|}
\hline Activity & Method of assay & Reference material & $\begin{array}{l}\text { No. of possible } \\
\text { methods of } \\
\text { expressing } \\
\text { results }\end{array}$ \\
\hline FSH & $\begin{array}{l}\text { Rat or mouse ovarian augmentation } \\
\text { assay (Steelman \& Pohley, 1953) }\end{array}$ & $\begin{array}{l}\text { 1st IRP-HMG } \\
\text { 2nd IRP-HMG } \\
\text { HMG-20A } \\
\text { NIH-FSH-S (1-3) } \\
\text { NIH-HPG-UPMI } \\
\text { Pergonal } 23 \\
\text { Armour Standard } \\
(264-151-x) \\
\text { i.u. for FSH }\end{array}$ & 8 \\
\hline \multirow[t]{4}{*}{ LH } & $\begin{array}{l}\text { Hypophysectomized rat prostate assay } \\
\text { (Loraine \& Brown, 1954) }\end{array}$ & $\begin{array}{l}\text { 1st IRP-HMG } \\
\text { 2nd IRP-HMG } \\
\text { HMG-20A } \\
\text { NIH-LH-S }(1-8) \\
\text { NIH-LH-B }(1-3) \\
\text { Armour Standard } \\
(227-80) \\
\text { Pergonal } 23 \\
\text { HCG } \\
\text { i.u for LF }\end{array}$ & 20 \\
\hline & $\begin{array}{l}\text { Ovarian ascorbic acid depletion } \\
\text { (Parlow, 1961) }\end{array}$ & $\begin{array}{l}\text { The above nine } \\
\text { standards }\end{array}$ & \\
\hline & $\begin{array}{l}\text { Seminal vesicle test in immature intact } \\
\text { male rats (Van Hell et al., 1964) }\end{array}$ & HCG & \\
\hline & $\begin{array}{l}\text { Immunological reaction (Wide et al., } \\
\text { 1961; Wide \& Gemzell, 1962) }\end{array}$ & HCG & \\
\hline $\begin{array}{l}\text { Total } \\
\text { gonadotrophic } \\
\text { activity }\end{array}$ & Mouse uterine weight test & $\begin{array}{l}\text { HMG-20A } \\
\text { lst IRP-HMG }\end{array}$ & \\
\hline
\end{tabular}

\section{METHODS OF ASSAY}

Before any FSH preparation can be used clinically its potency must be determined. The assays of total gonadotrophins, FSH and LH content that have been used and the reference preparations that may be employed are summarized in Table 1. Ignoring the possibility of different HCG doses, the results of ovarian augmentation assays in rats and mice (considered as one test) could be expressed in terms of at least eight types of reference preparation. The measurement of LH content has been or can be expressed in at least twenty ways. The total gonadotrophin assay need not be considered as it has been shown that the 
clinical effectiveness of a gonadotrophin preparation, as far as its initial effect on the ovaries is concerned, is a function of its FSH activity rather than its total gonadotrophin content (Bettendorf \& Breckwoldt, 1964, 1965). The ratio of FSH to LH could be of importance (Diczfalusy et al., 1964).

Assuming that the FSH and LH contents of any preparations used should be known, the chance of any two workers using the same assay combination is theoretically only 1 in 160 . Even with the same assay combination, significant differences in experimental design, statistical evaluation and the strains of animal used may exist.

Such factors constitute major obstacles to valid comparisons between one treatment schedule and another. Ideally, all preparations should be assayed by the same tests in the same laboratory using the same standards. In practice, one has to be content with conversion tables. The first column in Table 2 gives the

TABLE 2

OVARIAN AUGMENTATION ASSAY FOR FSH ACTIVITY

\begin{tabular}{c|l|c}
\hline $\begin{array}{c}\text { Approximate } \\
\text { correlation } \\
\text { factor }\end{array}$ & \multicolumn{1}{|c|}{ Reference material } & $\begin{array}{c}\text { Approximate strength of } \\
\text { preparation/mg in i.u. of } \\
\text { FSH activity }\end{array}$ \\
\hline 1.0 & NIH-FSH-s1 (see note 2) & 27 \\
2.3 & Armour Standard & 12 \\
3.3 & (264-151-x) & 8 \\
3.3 & Pergonal 23 & 8 \\
3.7 & 2nd IRP-HMG & $7 \cdot 2$ \\
187 & NIH-HPG-UPMI & 0.14 \\
187 & 1st IRP-HMG & $0 \cdot 14$ \\
27 & HMG-20A & \\
\hline
\end{tabular}

Notes: (1) The correlation factor relates the amounts of the various reference preparations which are equipotent in the ovarian augmentation assay. The higher the correlation factor, the lower the potency of the preparation.

(2) The activity ratios between NIH-FSH-S1/NIH-FSH-s2 and NIH-FSH-s3 are $1 \cdot 0 / 0 \cdot 87$ and $1 \cdot 1$ (National Institutes of Health data).

(3) The data for this Table has been obtained from Butt et al. (1965), Rosemberg et al. (1962) and Borth et al. (1961) and the description accompanying ampoules of NIH-HPG-UPMI.

approximate correlation factors between reference materials which have been or could be used in the measurement of FSH activity by the ovarian augmentation assay. The calculations were based on data given by Butt, Crooke \& Wolf (1965), Rosemberg, Engel \& Lewis (1962) and Borth, Lunenfeld \& Menzi (196l b), and the description which accompanies vials of NIH-HPG-UPMI. Recently an international unit (i.u.) for FsH activity has been established and the third column of Table 2 gives the strength per $\mathrm{mg}$ of various reference preparations in such units.

Table 3 shows the correlation factors between some of the reference preparations for LH obtained from data given by Butt et al. (1965) and Reichert (1965). The lack of analogy between ovarian ascorbic acid depletion (OAAD) and hypophysectomized rat prostate (HRP) assays is obvious. It has, however, been agreed that an i.u. for LH activity be established. The National Institute for 
Medical Research, Mill Hill, London, N.W.7, now issues, on behalf of the World Health Organization, ampoules of 2nd IRP-HMG containing 40 i.u. of FSH and 40 i.u. of LH or ICSH.

\section{METHODS OF PREPARATION AND PURIFICATION}

Gemzell, Diczfalusy \& Tillinger (1958) used lyophilized pituitaries as their starting material. After homogenization the glands were extracted in $\mathrm{Ca}(\mathrm{OH})_{2}$ solution and the gonadotrophin-containing material was prepared by ammonium sulphate fractionation. The yield per gland was 3 to $5 \mathrm{mg}$ of a product which had a potency of 0.5 to $1 \times$ NIH-FSH-s2 (12 to $24 \mathrm{i} . \mathrm{u} . / \mathrm{mg}$ according to Table 2) in the ovarian augmentation assay. The LH potency (Loraine \& Brown, 1954; Wide \& Gemzell, 1962) was about 25 i.u. of HCG $/ \mathrm{mg}$.

During the last few years at Uppsala, the preparation described above has

TABLE 3

CORRELATION FAGTORS FOR LH USING DIFFERENT METHODS OF ASSAY

\begin{tabular}{|c|c|c|c|}
\hline \multirow[b]{2}{*}{$\begin{array}{l}\text { HRP assay } \\
\text { correlation } \\
\text { factors }\end{array}$} & \multirow[b]{2}{*}{ Reference material } & \multicolumn{2}{|c|}{ OAAD assay } \\
\hline & & $\begin{array}{l}\text { Correlation } \\
\text { factors }\end{array}$ & $\begin{array}{l}\text { Strength of } \\
\text { preparation/mg in i.u. } \\
\text { LH activity }\end{array}$ \\
\hline $\begin{array}{l}1 \\
110 \\
\\
8 \cdot 3 \\
0 \cdot 76\end{array}$ & $\begin{array}{l}\text { NIH-LH-S1 } \\
\text { 1st IRP-HMG } \\
\text { 2nd IRP-HMG } \\
\text { Pergonal } 23 \\
\text { Armour Standard } \\
(227-80) \\
1 \text { i.u. of HCG } \\
\text { 1 i.u. of LH }\end{array}$ & $\begin{array}{c}1 \\
3000 \\
190 \\
190 \\
1 \cdot 1 \\
1900 \\
1500\end{array}$ & $\begin{array}{c}1500 \\
0 \cdot 5 \\
8 \\
8 \\
1300 \\
\\
0 \cdot 8\end{array}$ \\
\hline
\end{tabular}

Notes: (1) The correlation factor relates the amounts of the various reference preparations which are equipotent in a specified method of assay. The higher the correlation factor, the lower the potency of the preparation. $(1965)$.

(2) The data for this Table was obtained from Butt et al. (1965) and Reichert

been replaced by a product obtained from whole frozen pituitaries. The gonadotrophins were extracted according to the first step of a procedure developed by Roos for the isolation of pure FSH (Roos \& Gemzell, 1964, 1965). The yield of the clinical grade material was about $18 \mathrm{mg} /$ gland. The FSH activity was 1 to $1.5 \times$ NIH-FSH-S2 (24 to $35 \mathrm{i} . \mathrm{u} . / \mathrm{mg}$ ) and the LH activity 20 to 30 i.u. of HGG/mg. It follows that each gland gave 430 to 630 i.u. of FsH activity. This high value probably reflects a suitable starting material, mild extraction conditions and the fact that the preparation was completed in 1 day.

Fractionation of the clinical grade material by DEAE-cellulose column chromatography, gel filtration on Sephadex G-100 and zone-electrophoresis in polyacrylamide gel gave FSH with a potency of $425 \times$ NIH-FSH-s2 $(10,000$ i.u. $/ \mathrm{mg})$.

The essential part of the LH activity present in the clinical material was separated from the FSH activity by the step using DEAE-cellulose. However, even the material with the highest FSH potency has, according to preliminary biological assays, a certain LH activity. This activity amounts to about $0.5 \%$ of the 
luteinizing activity present in the most active LH preparations from human pituitaries. To give the correct interpretation of the $\mathrm{LH}$ activity in the highly purified FSH further chemical, biological and immunological studies are necessary. None of the highly purified fractions has yet been tried clinically.

Other extraction methods for human hypophysial FSH preparations used clinically have only been fully described by Crooke and co-workers and by Bettendorf and collaborators. The starting material for these preparations was acetone-dried pituitaries, treated by the method of Koenig \& King (1950). This involves extraction of FSH and $\mathrm{LH}$ in $40 \%$ alcoholic acetate buffer and precipitation of the gonadotrophins by increasing the alcohol concentration to $80 \%$. The material prepared by the German group (Bettendorf, Apostolakis \& Voigt, 1962) had an activity of 8 to $10 \times$ NIH-FSH-s1 (220 to 270 i.u. $/ \mathrm{mg}$ ) in the augmentation test. From the data given by Bettendorf et al. (1962) an activity yield of about $210 \mathrm{i}$.u./gland can be calculated. A recent estimate of the $\mathbf{L H}$ activity (Czygan, Breckwoldt \& Bettendorf, 1965) is $0.42 \times$ NIH-LH-B 1 by the ascorbic acid depletion method.

The material prepared according to Koenig and King by the English group was fractionated by chromatography on CM-cellulose, DEAE-cellulose and calcium phosphate (Butt, Crooke \& Cunningham, 1961). Three products of different purity were used clinically (Crooke, 1964; Crooke et al., 1963a, 1964a, b). The FSH activities were reported as 183 (26 i.u.), 1014 (140 i.u.) and 3000 to 4000 ( 420 to 560 i.u.) times the 1st IRP-HMG when measured by the augmentation assay and the corresponding LH activities were 265 (130 i.u.), 420 (210 i.u.) and 200 to 900 (100 to 450 i.u.) times the same standard when estimated by the OAAD assay. The values within the parentheses are the respective potencies/ mg calculated from data in Tables 2 and 3.

\section{THE SELECTION OF PATIENTS FOR TREATMENT}

Human gonadotrophin therapy should only be used on women who have an infertility problem. The ideal subject has been described as 'under 35, with normal, non-functioning ovaries, primary or long-standing secondary amenorrhoea, normally developed sex organs and complete lack of urinary gonadotrophins as evidence of pituitary failure' (Gemzell, 1965b). In practice, normal levels of urinary gonadotrophin do not exclude a diagnosis of pituitary deficiency and the value of the 'FSH test' as a method of exploring ovarian potential is mentioned later. The husband should be normally fertile. There should be no detectable barriers or contra-indications to conception and all other causes of amenorrhoea (psychiatric illness, pituitary or hypothalamic tumours, systemic disease, endocrine disorder outside the pituitary-ovarian axis, congenital malformations of the genital tract, hormone therapy and, of course, pregnancy) should have been excluded.

With critical evaluation, the number of patients ultimately chosen for treatment will be limited and will represent only a small percentage of those attending an infertility clinic.

HPFSH and HCG have been used on patients with the 'Stein-Leventhal' or 'polycystic ovary' syndrome (Crooke et al., 1963b; Edwards, 1964; Gemzell, 
1963c, 1965b; Mahesh \& Greenblatt, 1961, 1964). Although ovulation and normal patterns of sex steroid synthesis may result, gonadotrophins do not constitute the treatment of choice as these cases respond to other measures and may react to pituitary hormone therapy with undesirably rapid ovarian enlargement.

\section{DETECTION OF EFFECT}

The only absolute proof of induced ovulation is pregnancy. Short of this, various indirect methods of detecting follicular development, ovulation and corpus luteum formation have to be employed. As none of these is entirely reliable, the more that are used, the better.

\section{Sex steroid excretion patterns}

The main hormones produced by a ripening follicle are oestrogens. Progesterone comes from the corpus luteum. The work of Brown (1955) and Klopper (1957) suggests that a single follicle and corpus luteum are associated with a maximum total oestrogen excretion of $100 \mu \mathrm{g}$ and a peak pregnanediol output of $5 \mathrm{mg}$ in $24-\mathrm{hr}$ specimens of urine from the follicular and luteal phases of the menstrual cycle respectively. Theoretically, the sex steroid excretion pattern should give an accurate picture of ovarian activity.

Various reservations must, however, be made. It has been pointed out, for example, that excessively numerous unruptured follicles additively produce as much oestrogen and progesterone as a normal corpus luteum (Buxton et al., 1963). Crooke et al. (1963a) have noticed that there was a poor relationship between patterns of steroid excretion and menstrual bleeding. It has been calculated (Gemzell \& Roos, 1966a) that the average 24-hr excretion values of total oestrogens are only significantly higher in women who conceive triplets or more and that twin pregnancies, and hence superovulation, is not detected by these tests with any degree of accuracy. In the case of quintuplets described by Liggins \& Ibbertson (1966) daily total oestrogen determinations during FSH treatment gave no good evidence of overstimulation.

\section{Examination of vaginal smears and cervical secretions}

It has been shown that in the follicular phase of the menstrual cycle the karyopyknotic and eosinophilic indices (KI and EI) of the vaginal smear show a significant correlation with the logarithms of the total oestrogen excretion (Johannison, Gemzell \& Diczfalusy, 1961). The simplicity and speed of these tests make them a worth-while source of information.

The consistency and volume of cervical mucus give some help in assessing follicular development. The arborization pattern is sometimes used in the detection of ovulation. The mechanism and significance of these tests has been discussed by Zondek (1954).

\section{Basal body temperature (BBT)}

The biphasic pattern of the ovulatory cycle is well known. Again, simplicity makes BBT shift a useful test in a patient under treatment with gonadotrophins. 
Ovarian palpation and inspection

Frequent bimanual pelvic examination is important during treatment. The appearance of clinically obvious ovarian enlargement usually means excessive follicular development. It is important to exercise care during palpation. The ovary that is overstimulated by gonadotrophins is friable and easily ruptured.

The presence of a corpus luteum at laparotomy or culdoscopy affords proof of ovulation. The disadvantages inherent in these methods of detection are obvious.

\section{Endometrial histology}

Secretory changes in endometrium obtained by biopsy or curettage imply corpus luteum formation and ovulation. Naturally, such procedures are contraindicated in patients who are trying to conceive.

\section{TREATMENT SGHEDULES}

The ideal result of treatment is pregnancy resulting from fertilization of a single ovum released at a predictable time by induced ovulation. FSH followed by HGG is the usual therapeutic pattern.

The response a patient shows will depend on a number of factors: the metabolism and excretion rates of the hormones given, the state of the ovaries, the level of endogenous gonadotrophin production, the possible presence of gonadotrophin-inhibiting substances, the FSH/LH ratio of the preparation used, the total dosages of FSH and HGG and the timing of their administration. It is the latter three variables which can be influenced during therapy.

FSH/LH ratio

Diczfalusy et al. (1964) found that a pituitary extract with an FSH/LH ratio of $2 \cdot 3$ was effective at lower doses (measured as FSH activity) than a urinary one with a ratio of $0 \cdot 37$. Crooke et al. (1963a) similarly found that preparations with the least amount of $\mathrm{LH}$ gave the best results. In a limited trial, Gemzell \& Roos (1966a) noted that a preparation of FSH with 7 NIH-FSH-s2 units (98 i.u.) of FSH activity and $100 \mathrm{HCG}$ units of LH activity/mg gave no better results than extracts with relatively higher $\mathbf{L H}$ contamination. There may well be an optimal $\mathbf{~ F S H / L H}$ ratio above which no increase in effect is achieved and below which there is a loss of potency.

\section{Total dosages of FSH and $\mathrm{HCG}$}

For reasons previously stated and summarized in Table 1, comparisons between one author and another are extremely difficult and must be regarded as very approximate. Using the information in Table 2 it can be calculated that effective total dosages given over 10 to 14 days have ranged from 3000 to 15,000 1st IRP-HMG units or 54 to 270 2nd IRP-HMG units or 16 to $80 \mathrm{NIH}-\mathrm{FSH}-\mathrm{s} 1$ units or 432 to 2160 i.u. of FSH activity. These figures are derived from reports on treatment with pituitary and urinary extracts of FSH. In this clinic, ten daily doses, each with an FSH activity of about 730 1st IRP-HMG units or 13 2nd IRP-HMG units or 4 NIH-FSH-s1 units or 108 i.u. are now used. HPFSH appears to have an 
'all or none' action, with little difference between the dose that overstimulates and the dose that has no effect. It would seem desirable to keep Fsh doses as low as possible. A preliminary 'FSH test' with careful assessment of resulting ovarian activity may help to achieve this aim. It may also be useful as a method of determining whether the responsiveness of the ovaries is sufficient to warrant attempts at induced ovulation. It has also been suggested that the ovary is less likely to be overstimulated during a second course of treatment. Were this so, it would be an added reason for advocating an 'FSH test' as a routine preliminary.

Some have recommended individualization of treatment with flexibility of dosages. They believe that decisions about their size should be made from day to day with oestrogen excretion levels, vaginal cytology, the volume of cervical mucus (Lunenfeld, 1965; Vande Wiele \& Turksoy, 1965) and its arborization pattern (David, Insler \& Ber, 1964) as measures of follicular development.

HCG is usually given after the follicles have been primed with FSH in amounts between 9000 and 45,000 i.u. over 1 to 6 days. Ovulation may also occur without the addition of HCG (Bettendorf, 1962, 1963, 1964; Bettendorf \& Breckwoldt, 1964, 1965). The original claim that this avoided overstimulation has not been substantiated.

\section{Timing of FSH and HCG administration}

This has been extensively investigated by Crooke et al. (1963a, 1964b) using experiments of statistical design on a series of nine patients. With patients of steroid excretion as their criteria, they considered that the most normal response was likely to occur when the FSH is divided into three equal doses over 8 days and HGG is given as a single injection after an interval of under $96 \mathrm{hr}$ after the third dose.

The timing of treatment has also been assessed here with predictability of ovulation, the number of treatments required before conception (the 'treatment/ pregnancy' ratio) and the proportion of patients treated who conceived (the 'patient/success' ratio) as the measures of success. Daily HPFSH for 10 days, followed 24 to $48 \mathrm{hr}$ later by HCG for 3 days gave the best results. The frequency of multiple births was high, but the 'treatment/pregnancy' and 'patient/ success' ratios were both around 2 (Gemzell \& Roos, 1966a). HPFSH administration for 4 to 6 days with a gap of 2 to 3 days before HCG gave lower levels of total oestrogen excretion but the pregnancy rate seemed to fall and the time of ovulation became less predictable. HPFSH and HCG given together from the onset of treatment appeared to have the same effect.

It has been suggested that the timing of HCG should depend on the vaginal smears, studies of cervical mucus and the results of post-coital tests (Vande Wiele \& Turksoy, 1965). At the present time it seems unlikely that booster doses of HGG are necessary to maintain the corpus luteum of pregnancy until the trophoblastic cells start secreting hormones.

\section{COMPLICATIONS OF TREATMENT}

The lack of agreement about dosage and timing is symptomatic of the complications which attend gonadotrophin therapy. These centre round overstimulation of the ovaries. 
Superovulation and multiple pregnancy

The incidence of multiple pregnancy after gonadotrophin therapy is high. Gemzell \& Roos (1966a) have found that of forty-three patients delivered, fourteen $(33 \%)$ had twins and nine $(20 \%)$ triplets or more. Crooke's latest figures (Lancet Annotation, 1965) show two sets of twins (20\%) in ten completed pregnancies. July 1965 saw the birth of quintuplets (Lancet Annotation, 1965; Liggins \& Ibbertson, 1966) in New Zealand and Sweden. The former set survived and of the latter, delivered at 28 weeks, only one lived. A pregnancy with seven foetuses has been recorded and ended in abortion (Gemzell \& Roos, 1966a). The higher risks and increased foetal wastage of multiple births naturally make their occurrence undesirable.

The reason for the variable rates of multiple birth is not clear. It is generally felt that exogenous FSH in effective doses inevitably stimulates more than one follicle. Thus it may be that a high incidence of multiple births reflects the results of treatment which leads to the accurately predictable but simultaneous rupture of many follicles - 'synchronous superovulation'-rather than a possibly haphazard and hence unpredictable rupture of the same number of follicles over a longer period of time--'sporadic superovulation'. If this were so it would make it difficult to design a regime which combines good 'treatment/pregnancy' and 'patient/success' ratios with a low incidence of multiple births. For these reasons it is of interest to know both ratios of all series reported, particularly those with the smallest percentage of multiple pregnancy.

\section{The 'hyperstimulation syndrome'}

Rapid ovarian enlargement with intra-peritoneal effusions or haemorrhages may be seen. Gemzell (1963c) encountered the 'hyperstimulation syndrome' four times in 200 treatments. In another series (Mozes, Bogokowsky, Antebi, Rabau, Serr, David, Salomy \& Lunenfeld, 1965) it occurred in twelve out of 158 treatments. A case of ascites and pleural effusion, as in Meigs's syndrome, has been reported after overstimulation (Neuwirth, Turksoy \& Vande Wiele, 1965b). No fatalities have been recorded with HPFSH. In the death reported by Mozes et al. (1965) hyperstimulation followed HMG-HCG therapy and was associated with vascular complications. In the days of PMS and HCG two deaths were reported (Esteban-Altirriba, 1961).

In treating a patient with abdominal symptoms due to overstimulation, conservative management should be sufficient. The signs and symptoms usually regress with bed-rest. Intravenous replacement of fluid lost into the peritoneal cavity may be necessary. Only if the patient deteriorates while under observation should laparotomy be contemplated for the purpose of evacuating intra-peritoneal effusions. Ovarian resection should be avoided because of the technical difficulty of conservative surgery on overstimulated ovaries.

\section{Thrombo-embolic phenomena}

Two cases of thrombo-embolism following HMG-HCG have been reported (Mozes et al., 1965). Both were associated with ovarian hyperstimulation and peritoneal effusions. In one, femoral venous and arterial thromboses led to a below-knee amputation. In the other, death followed left internal carotid 
artery occlusion. It is suggested that these vascular accidents may have been due to rapid fluid shifts or to abnormal oestrogen and progesterone levels after follicular stimulation.

Crooke et al. (1964a) recorded a case of deep-vein thrombosis at 12 weeks of pregnancy following ovulation induced with HPFSH-HGG. A puerperal deep-vein thrombosis occurred in the woman who delivered surviving quintuplets. To date these are the only thrombotic episodes described after HPFSH and the association between treatment and disease is doubtful in each case.

\section{PREGNANCY AFTER INDUCED OVULATION}

About seventy cases of pregnancy following HPFSH-HCG therapy have been described (Bettendorf \& Breckwoldt, 1964; Bettendorf et al., 1964; Buxton et al., 1963; Crooke et al., 1964a; Edwards, 1964; Gemzell \& Roos, 1966a; Liggins \& Ibbertson, 1966). The largest series numbers forty-three (Gemzell \& Roos, 1966a). Between forty and fifty pregnancies after HMG-HCG have been reported (Buxton et al., 1963; Diczfalusy et al., 1964; Lunenfeld, 1963, 1965; Lunenfeld et al., 1961, 1962; Neuwirth, Todd, Turksoy \& Vande Wiele, 1965a; Pasetto \& Montanino, 1964a, b; Polishuik, Palti, Rabau, Lunenfeld \& David, 1965) and the largest group of twenty is Vande Wiele's.

The problems of multiple pregnancy have already been mentioned. The frequent occurrence of bleeding in early pregnancy has been noted by some. There seems to be an increased incidence of abortion, the highest rate quoted being $50 \%$ (Vande Wiele \& Turksoy, 1965). In this clinic, this complication was usually associated with multiple pregnancy and occurred in the second trimester. Rupture of an ovarian 'hyperstimulation cyst' in early pregnancy has been seen (Pasetto \& Montanino, 1964b). This patient miscarried at 7 weeks, 9 days after a laparotomy and bilateral ovarian cystectomy. Placental insufficiency appears to be a feature of one series (Edwards, 1964; Crooke et al., 1964a). One case of ectopic pregnancy following HPFSH-HCG occurred recently in Sweden.

The only foetal abnormality is recorded by Crooke et al. (1964a). A macerated stillborn male foetus (one of binovular twins) showed a small lumbar spina bifida and an unusually broad and high bridge of nose. In this clinic all infants born, as well as most foetuses from abortions, have been examined and no congenital malformation has as yet been noted. The first two patients treated successfully were both delivered of twins in January 1960 and none of the four children, now 6 years old, shows any sign of mental or physical defect. It is encouraging to note that animal experiments with induced ovulation seem to reveal no abnormality in the maturation of oocytes (Hafez \& Ishibashi, 1964).

\section{CONCLUSION}

The last 40 years have seen great advances in the field of gonadotrophins and their clinical use. It is likely and desirable that at least as much progress is made in the next four decades. The problems of superovulation, improved methods for the assay of FSH and LH with agreement about international standards, and the chemical structure and even synthesis of these hormones will probably receive 
much attention. It is perhaps apt to recall now the words which Zondek wrote in 1931 as the conclusion to his book about the anterior pituitary:

'I am certainly aware that many of the problems mentioned are not fully solved and that some await solution. But I believe that a few matters of importance have been clarified so that the current findings are not without practical and theoretical significance. With the advance of research it is possible that some of the views expressed ... will be revised. If just a few of them become established scientific fact then the purpose of the preceding investigations will have been fulfilled' (Zondek, 1931).

\section{REFERENCES}

Apostolakis, M., Bettendorf, G. \& Voigt, K. D. (1962) Klinisch-Experimentelle Studien mit Menschlichen Hypophysären Gonadotropin. Acta endocr., Copenh. 41, 14.

Aschrerm, S. (1926) Über die Funktion des Ovariums. Z. Geburtsh. Gynäk. 90. 387.

Aschнeim, S. \& ZoNDEK, B. (1927) Hypophysenvorderlappenhormone und Ovarial-hormon in Harn von Schwangeren. Klin. Wschr. 6, 1322.

BetTendoRf, G. (1962) Beeinflussung der hypogonadotropen Ovarialinsuffizienz durch hypophysären Human-Gonadotropin. Geburtsh. Frauenheilk. 22, 928.

Bettendorf, G. (1963) Human hypophyseal gonadotropin in hypophysectomised women. Int. 7 . Fert. 8, 799.

BetTendorf, G. (1964) Human hypophyseal gonadotropin (HHG) and its clinical effects. Int. $\mathcal{F}$. Fert. 9, 351.

Bettendorf, G., Apostolakis, M. \& Voigt, K. D. (1962) Darstellung von Gonadotropin aus Menschlichen Hypophsen. Acta endocr., Copenh. 41, 1.

BetTendoRF, G. \& BREcKWoldT, M. (1964) Klinisch-experimentelle Untersuchungen mit hypophysären Human-Gonadotropin. Arch. Gynaek. 199, 423.

BETtendoRf, G. \& BRECKWOLdT, M. (1965) Wirkung des hypophysären Humangonadotropins (HHG) bei der hypogonadotropen Ovarialinsuffizienz. Z. Geburtsh. Gynäk. 21, 31.

Bettendorf, G., Breckwoldt, M., Knörr, K. \& Stegner, H. E. (1964) Gravidität nach Hypophysektomie und Behandlung mit hypophysären Humangonadotropin. Dt. med. Wschr. 89, 1952.

Borth, R., Lunenfeld, B. \& Menzi, A. (1961a) Effect of method of bio-assay on relative potency of gonadotropin preparations from human urine. Human Pituitary Gonadotropins, p. 153. Ed. A. Albert. Charles C. Thomas, Springfield, Illinois.

Borth, R., Lunenfeld, B. \& MENZI, A. (1961b) Pharmacologic and clinical effects of a gonadotropin preparation from human post-menopausal urine. Human Pituitary Gonadotropins, p. 255. Ed. A. Albert. Charles C. Thomas, Springfield, Illinois.

BRown, J. B. (1955) Urinary excretion of oestrogens during the menstrual cycle. Lancet, i, 320.

Buxton, G. L. (1961) Anovulation due to pituitary failure-diagnosis and treatment. Proc. R. Soc. Med. 54, 297.

Buxton, C. L. \& HerrmanN, W. (1960) Induction of ovulation in the human with human gonadotropins. Tale 7. Biol. Med. 33, 145.

Buxton, C. L. \& Herrmann, W. (1961) Induction of ovulation in the human with human gonadotropins. Am. F. Obstet. Gynec. 81, 584.

Buxton, C. L., Kase, N. \& VAN Orden, C. (1963) The effect of PSH and HCG on the anovulatory ovary. Am. 7. Obstet. Gynec. 87, 773.

Butt, W. R., Grooke, A. C. \& Cunningham, F. J. (1961) Studies on human urinary and pituitary gonadotrophins. Biochem. F. 81, 596.

Butr, W. R., CRooke, A. C. \& Wolf, A. (1965) Some problems related to the investigation of the immunological properties of human pituitary follicle-stimulating hormone. Ciba Fdn Study Grps. No. 22, 85 .

CROOKE, A. C. (1964) The clinical effect of human pituitary and urinary gonadotropins. Proc. R. Soc. Med. 57, 111.

Crooke, A. C., Butt, W. R., Palmer, R. F., Morris, R., Edwards, R. L. \& Anson, G. J. (1963a) Clinical trial of human gonadotropins. $\mathrm{I}$. The effect of pituitary and urinary follicle stimulating hormone and chorionic gonadotropin on patients with idiopathic secondary amenorrhoea. $\mathcal{F}$. Obstet. Gynaec. Br. Commonw. 70, 604. 
Crooke, A. C., Butt, W. R., Palmer, R., Morris, R., Edwards, R. L., Taylor, C. W. \& Short, R. V. (1963b) Effect of human pituitary follicle-stimulating hormone and chorionic gonadotrophin in Stein-Leventhal syndrome. Br. med. F. i, 1119.

Crooke, A. C., Butt, W. R., Carrington, S. P., Morris, R., Palmer, R. F. \& Edwards, R. L. (1964a) Pregnancy in women with secondary amenorrhoea treated with human gonadotrophins. Lancet, i, 184.

Crooke, A. C., Butt, W. R., Palmer, R. F., Bertrand, P. V., Carrinton, S. P., Edwards, R. L. \& Anson, C. J. (1964b) Clinical trial of human gonadotrophins. II. The effect of pituitary and urinary follicle stimulating hormone and chorionic gonadotrophin in patients with idiopathic secondary amenorrhoea. 7. Obstet. Gynaec. Br. Commonw. 71, 571.

Crooke, A. C., Butt, W. R., Palmer, R. F., Morris, R. \& Morgan, D. B. (1964c) The effect of human gonadotrophins on a patient with Simmonds's disease. Acta endocr., Copenh. 46, 292.

Czygan, P. J., Breckwoldt, M. \& Bettendorf, G. (1965) Purification of Fsh and LH from human hypophyseal gonadotropin. Acta endocr., Copenh. 50, Suppl. 100, 113.

David, A., Insler, V. \& Ber, R. (1964) The Fern test in following treatment with human gonadotropins. Proc. Tel-Hashomer Hosp. 3, 193.

Diczfalusy, E., Johannison, E., Tillinger, K. G. \& Bettendorf, G. (1964) Comparison of the clinical and steroid metabolic effect of human pituitary and urinary gonadotropins in amenorrhoeic women. Acta endocr., Copenh. Suppl. 90, 35.

Donini, P., Puzzuoli, D. \& Montezemolo, R. (1964) Purification of gonadotrophin from human menopausal urine. Acta endocr., Copenh. 45, 321.

EDWArds, R. L. (1964) The therapeutic effects of human pituitary gonadotrophins. Proc. R. Soc. Med. $57,927$.

Esteban-AltirRiba, J. (1961) Le syndrome d'hyperstimulation massive des ovaires. Revue fr. Gynéc. Obstét. 56, 555.

Fluhmann, C. F. (1929) Anterior pituitary hormone in blood of women with ovarian deficiency. $\mathcal{J}$. Am. med. Ass. 93, 672.

Gemzell, C. A. (1961) The induction of ovulation in the human by human pituitary gonadotrophin. Control of Ovulation, p. 192. Ed. C. A. Villee. Pergamon Press, London.

Gemzels, C. A. (1962a) Induction of ovulation with human gonadotrophins. Acta endocr., Copenh. Suppl. 67, 49.

Gemzels, C. A. (1962b) Induction of ovulation with human pituitary gonadotrophins. Fert. Steril. 13, 153.

Gemzell, C. A. (1963a) Purified protein hormones in human endocrinology. Techniques in Endocrine Research, p. 213. Ed. P. Eckstein and F. Knowles. Academic Press, London.

GemzelL, C. A. (1963b) Induction of ovulation in the human by human gonadotrophins. Progress in Gynaecology, Vol. IV, p. 196. Eds. J. V. Meigs and S. H. Sturgis. Grune \& Stratton, New York.

GemzeLL, C. A. (1963c) The use of human gonadotropins in gynaecological disorders. Modern Trends in Gynaecology, p. 133. Ed. R. J. Keller. Butterworths, London.

Gemzell, G. A. (1964) Therapy of gynaecological disorders with human gonadotropin. Vitams Horm. $22,129$.

Gemzell, C. A. (1965a) Induction of ovulation with human gonadotropins. Recent Prog. Horm. Res. 21, 285.

Gemzell, C. A. (1965b) Induction of ovulation with human gonadotropins. Proc. IInd int. Congr. Endocrinology, Part 11, p. 805. Ed. S. Taylor. Excerpta Medica Foundation, Amsterdam.

Gemzell, C. A., Diczfalusy, E. \& Tillinger, K. G. (1958) Clinical effect of human pituitary folliclestimulating hormone (FSH). F. clin. Endocr. Metab. 18, 1333.

Gemzele, C. A., Diczfalusy, E. \& Tillinger, K. G. (1960) Human pituitary follicle-stimulating hormone. I. Clinical effect of a partially purified preparation. Ciba Fdn Colloq. Endocr. 13, 191.

Gemzell, G. A. \& Roos, P. (1966a) Pregnancies following treatment with human gonadotropins with special reference to the problem of multiple births. Am. 7. Obstet. Gynaec. 94, 490.

Gemzezl, C. A. \& Roos, P. (1966b) Treatment of sterility with human gonadotropins. Adv. Obstet. Gynaec. (In press).

Grant, A., Meares, S. D., Ferguson, K. A. \& Wallace, A. L. C. (1964) The treatment of anovulation by human pituitary gonadotrophin. Aust. N.Z. J. Obstet. Gynaec. 4, 39.

HAFEz, E. S. E. \& IshIBASHI, I. (1964) Maturation division of oocytes in bovine following gonadotrophin injections. Cytogenetics, 3, 167.

Johannison, E., Gemzell, C. A., Diczfalusy, E. (1961) Effect of a single injection of human pituitary follicle-stimulating hormone on urinary estrogens and the vaginal smear in amenorrhoeic women. F. clin. Endocr. Metab. 21, 1068.

KLOPPER, A. I. (1957) The excretion of pregnanediol during the normal menstrual cycle. 7. Obstet. Gynaec. Br. Emp. 64, 504. 
Koenig, V. L. \& KING, E. (1950) Extraction studies of sheep pituitary gonadotrophic and lactogenic hormone in alcoholic acetate buffers. Archs Biochem. 26, 219.

Kotz, H. L. \& HerrmanN, W. (1961) A review of the endocrine induction of human ovulation. Fert. Steril. 12, 375.

Lancet Annotation. (1965) Pituitary gonadotrophin and multiple pregnancy. Lancet, ii, 277.

Liggins, G. C. \& IBberTson, H. K. (1966) A successful quintuplet pregnancy following treatment with human pituitary gonadotrophins. Lancet, i, 114.

Loraine, J. A. \& Brown, J. B. (1954) Some observations on the estimation of gonadotropins in human urine. Acta endocr., Copenh. 17, 250.

LunENFELD, B. (1963) Treatment of anovulation by human gonadotrophins. F. int. Fed. Gynaec. Obstet. $1,153$.

Lunenfeld, B. (1965) Urinary gonadotropins. Proc. Ind int. Congr. Endocrinology, Part II, p. 814. Ed. S. Taylor. Excerpta Medica Foundation, Amsterdam.

Lunenfeld, B., Menzi, A. \& Volet, B. (1960) Clinical effects of human postmenopausal gonadotrophin. Acta endocr., Copenh. Suppl. 51, 587.

Lunenfeld, B., RABaU, E., RuMNey, G. \& Winkelsberg, G. (1961) The responsiveness of the human ovary to gonadotrophin. Proc. IIIrd World Congr. Gynaecology and Obstetrics (Vienna), vol. 1, p. 220. Congressprint, Romayor, Vienna.

LuneNFeld, B., Sulimovici, S. \& RABAu, E. (1962) Urinary gonadotropins in treatment of pituitary amenorrhoea. Proc. Tel-Hashomer Hosp. 1, 25.

Mahesh, V. B. \& Greenblatt, R. B. (1961) Physiology and pathogenesis of the Stein-Leventhal syndrome. Nature, Lond. 191, 888.

MAHESh, V. R. \& Greenblatt, R. B. (1964) Urinary steroid excretion patterns in hirsutism. II. Effect of ovarian stimulation with human pituitary FSH on urinary 17 -ketosteroids. $\mathcal{F}$. clin. Endocr. Metab. 24, 1293.

Mozes, M., Bogokowsky, H., Antebi, E., Rabau, E., Serr, D. M., David, A., Salomy, M. R. \& LUNENFELD, B. (1965) Thrombo-embolic phenomena following ovarian stimulation with human gonadotropins. Lancet, ii, 1213.

Muller, P. (1962) Incidents et Accidents Consecutifs à l'Administration de Gonadotrophines chez la Femme. Les Gonadotrophines en Gynécologie, p. 137. Masson, Paris.

Neuwirth, R. S., Todd, W. D., Turksoy, R. N. \& VANDE Wiele, R. L. (1965a) Successful quadruplet pregnancy in a patient treated with human menopausal gonadotropins. Am. 7. Obstet. Gynec. $91,982$.

Neuwirth, R. S., Turksoy, R. N., VANDE Wiele, R. L. (1965b) Acute Meigs's syndrome secondary to ovarian stimulation with human menopausal gonadotropins. Am. F. Obstet. Gynec. 91, 977.

OstergaARD, E. (1964) Incidence and rate of appearance and disappearance of antigonadotrophin in the blood of patients treated with pregnant mare's serum. Acta endocr., Copenh. Suppl.90, 235.

Palmer, R. \& Dorangeon, P. (1962) Premiers essaies personnels de traitement de sterilités anovulaires par l'association hMg plus HcG. C.r. Soc. fr. Gynéc. 32, 407.

PARLOW, A. F. (1961) Bio-assay of pituitary luteinizing hormone by depletion of ovarian ascorbic acid. Human Pituitary Gonadotropins. Ed. A. Albert. Charles C. Thomas, Springfield, Illinois.

Pasetto, N. \& Montanino, G. (1964a) Induction of ovulation by human gonadotrophins. Acta endocr., Copenh. 47, 1.

Pasetro, N. \& Montanino, G. (1964b) La gonadotropine umane urinarie nella terapia della amenoree. Minerva ginec. 16, 377.

Polishuik, W. Z., Palti, Z., Rabau, E., Lunenfeld, B. \& David, A. (1965) Pregnancy in a case of Sheehan's syndrome following treatment with human gonadotrophins. $\mathcal{J}$. Obstet. Gynaec. Br. Commonw. 72, 778.

Reichert, L. A. (1965) Comparative studies on luteinizing hormone. Ciba Fdn Study Grps, No. 22, 30.

Roos, P. \& Gemzell, C. A. (1964) The isolation of human pituitary follicle-stimulating hormone. Biochim. biophys. Acta, 82, 218.

Roos, P. \& GemzelL, C. A. (1965) Preparation of human rsh from pituitaries and from post-menopausal urine. Ciba Fdn Study Grps, No. 22, 11.

Rosemberg, E., Enger, I. \& LeWIs, W. (1962). Comparative activities of human gonadotropins. 7 . clin. Endocr. Metab. 22, 853.

Rosemberg, E., Coleman, J., Demany, M. \& Cerso-Ramon, G. (1963) Clinical effect of human urinary postmenopausal gonadotrophin. F. clin. Endocr. Metab. 23, 181.

Rosemberg, E., Coleman, J., Gibree, H. \& MacGillivray, W. (1962) Clinical effect of gonadotrophins of human origin. Fert. Steril. 13, 220.

Rosemberg, E., Maher, R. E., Stern, A. \& Demany, M. (1964) Clinical effect of gonadotrophins of human origin. Case report with a two-year follow-up. F. clin. Endocr. Metab. 24, 105.

SmITH, P. E. (1926) Hastening development of female genital system by daily homoplastic pituitary transplants. Proc. Soc. exp. Biol. Med. 24, 131. 
Smith, P. E. \& Engle, T. E. (1927) Experimental evidence regarding the role of the anterior pituitary in the development and regulation of the genital system. Am. F. Anat. 40, 159.

Staemmler, J.J. (1961) Die Anwendung von Gonadotropinen im Regulation des Ovarial-Endokrinium. Berichten. III. Weltkongress für Gynäkologie und Geburtshilfe, Wien. Congressprint, Romayor, Wien.

Steelman, S. L. \& Pohley, F. M. (1953) Assay of the follicle stimulating hormone based on the augmentation with human chorionic gonadotropin. Endocrinology, 53, 604.

Van Hell, H., Matthissen, R. \& Overbeek, G. A. (1964) Effects of human menopausal gonadotrophins in different bioassay methods. Acta endocr., Copenh. 47, 409.

VAnde Wiele, R. L. \& Turksoy, N. (1965) Treatment of amenorrhoea and of anovulation with human menopausal gonadotropins. F. clin. Endocr. Metab. 25, 369.

Wide, L. \& Gemzeli, C. A. (1962) Immunological determination of pituitary luteinizing hormone in the urine of fertile and post-menopausal women and adult men. Acta endocr., Copenh. 39, 539.

Wide, L., Roos, P. \& GEMSELl, C. A. (1961) Immunological determination of human pituitary luteinizing hormone (LH). Acta endocr., Copenh. 37, 445.

Zondek, B. (1926) Uber die Funktion des Ovariums. Z. Geburtsh. Gynäk. 90, 372.

Zondek, B. (1930) Uber die Hormone des Hypophysenvorderlappen. Klin. Wschr. 9, 679.

ZoNDEK, B. (1931) Die Hormone des Ovariums und des Hypophysenvorderlappens. Springer, Berlin.

ZoNDEx, B. (1954) Some problems related to ovarian function and to pregnancy. Recent Prog. Horm. Res. 10, 395. 